\title{
The Influence of Self-media on the Ideological and Political Education in Higher Vocational College
}

\author{
Xiaoqun Zhang and Jingyu Xu \\ HAINAN College of Software Technology Hainan 5714002
}

Keywords: Self-media; Students; Ideological and political education; Counter-measures

\begin{abstract}
With the popularization and development of the Internet and the extensive use of electronic products, Self-media has become an important part of people's lives, profoundly affecting people's way of life and communication. And the current higher vocational students are influenced by the most profound influence from Self-media, which is bound to the current ideological and political education of the students cannot be ignored, and even impact. Based on the analysis of higher vocational students, this paper expounds the positive and negative influence of We- media popularization on these students' ideological and political education, and explores the countermeasures and methods to enhance the effectiveness of ideological and political education in higher vocational colleges.

With the development of Internet technology, micro-blog, We chat, QQ and other information technology has been very widely used. These Self-media have become the important communication methods of the students in higher vocational colleges, and also have a great influence on the current ideological and political education. Therefore, this paper will first analyze the basic characteristics of the media, on the basis of revealing the positive influence from the media for ideological and political education and the negative effect of dialectical analysis of its advantages and disadvantages, and then according to these negative effects and puts forward some countermeasures and suggestions. It is expected that this paper will provide the inspiration for the relevant higher vocational colleges to carry out the ideological and political education of students in the background of the media age.
\end{abstract}

\section{Analysis of Basic Characteristics of Self-media}

As a new type of communication, Self-media has many new features that are not existed in the traditional communication channels. Some of the main includes the following aspects.

Participation in the Autonomy. From the background of the media technology, everyone can become the information provider. Higher vocational students can also through the mobile phone, Internet and other forms, to participate in the information acquisition and transmission process. That means Self-media is convenient for higher vocational students to access information, no longer rely on schools and parents information, many higher vocational students to obtain information even far more than the parents and teachers, and the content of information is difficult to fully grasp by educators. Autonomy is one of the important characteristics of Self-media. In addition, in Self-media environment, his participation of the main body is equal, it can be both the recipient and disseminator of information, and accessed the same information, which may also have the same negative impact. The traditional information channels haven't this equality.

Complexity of Information. Self-media is carrying the complicated information, and it is very rich and varied video, web pages, pictures, sounds, etc., all kinds of information can be spread through Self-media. It's hard to distinguish the information is good or bad. For the growing students, the authenticity of information for their world view, outlook on life, the formation of values is extremely important. However, vocational students often don't have the ability to distinguish and make a screening of information when face to the complex information. Therefore, the complexity of information is another feature of Self-media. The complexity is the performance of large amounts of information, the sources and authenticity of information also more difficult to distinguish. 
Spread Fast and Simple. The dissemination of information from Self-media is very rapid. In the information age, information can be spread instantly. In addition, the dissemination of information in the process, the communicator is also very simple to complete the information transmitted, as information disseminators [1]. For example, the "Moments" of Wechat, when you see the relevant information, users can quickly complete the forwarding of information, and is very simple to operate. The speed of information dissemination and the simplicity of communication are important characteristics of the information from the background of the media. Spread fast is expanded the influence of information, information, if it's positive energy will have a positive impact to the society, but negative information do the opposite.

All in all, only better to grasp the characteristics of the above Self-media information dissemination, in order to put forward the specific countermeasures, and reduce these technologies for the new media impact on ideological and political education work.

\section{The Influence of Self-media on the Ideological and Political Education in Higher Vocational College}

Self-media has two sides, it has both positive and negative effects of college students, opportunities and challenges in ideological and political education [1]. Therefore, we must to see two sides of this new technology, dialectical to see the impact of the media on the ideological and political education.

Positive Effects of Self-Media in Ideological and Political Education. Compared with the traditional ideological and political education, it is often based on the indoctrination of the text books, but for the current vocational students, this single mode of education is not enough, cannot be well accepted by students. The emergence of Self-media, to reform the traditional ideological and political education methods to provide a new channel or ideas. Colleges and teachers, can take full advantage of Self-media means, combined with the actual preference of contemporary students, with new means to carry out ideological and political education [2]. This is very important for the future development of the ideological and political education. In addition, in the era of Self-media, network communication is convenient and the huge amount of information has been recognized and accepted by higher vocational college students [2]. The positive influence brought by Self-media is conducive to enhancing the effectiveness of ideological and political education, and becomes a new channel for ideological and political education. This is the reform or innovation of traditional ideological and political education.

Negative Effects of Self-media in Ideological and Political Education. Self-media has both positive and negative effects. The main negative effects are as follows:

The first is the existence of a number of negative messages. Information from the media mixed with negative information, such as pornographic information, violent information, etc., this negative information on the judgments of vocational students is extremely influential. In this context, the negative content of media information will undoubtedly affect the formation of correct world outlook, values and outlook on life of vocational students. The second is over-indulging in the network, to distract the student's learning attention. For the situation of vocational students, they long indulged in the network, such as Wechat, QQ, even in class time to use these Self-media, not study hard, seriously affected the classroom teaching. The third is the possibility of fraud by the network, which makes the students trapped in the hardship. Now online fraud is rampant, vocational students because of the lack of relevant information screening ability, which often become victims of property damage. The fourth is the ability of information screening is poor, the forwarding of some illegal information to become the disseminator of bad information, and extremely easy to lead to illegal, vocational students cannot forward their own information to identify. All in all, these adverse effects will make the ideological and political education work suffered shock. This impact cannot be ignored, for the education of vocational students, the need to continue to receive positive information guidance, and gradually form the correct "three view." In this context, vocational schools must pay attention to these negative effects, to take effective measures to improve the current ideological and political education, to achieve results of ideological and political education. 


\section{Countermeasures of Strengthening the Ideological and Political Education of Higher Vocational Students in Self-media Background}

The negative impact of Self-media on the ideological and political education of higher vocational college students cannot be ignored, in order to enhance the effectiveness of ideological and political education; we must take measures to improve the ideological and political education. To take countermeasures against the negative effects.

Strengthen Self-media Platform Construction. As the main body of ideological and political education, education departments should strengthen the establishment of the relevant self-media platform construction, and attract students to join these self-media platform. For example, the school to establish the ideological and political education of the client, APP, through these platforms in a timely manner to release relevant information, to strengthen the ideological and political education of students, and to formed virtually impact of students. As another example, the ideological and political education of higher vocational teachers, can build a classroom learning group counseling team communication, through classroom education combined with extracurricular guidance, to ideological and political education work through to the student's life, into the students' daily network information retrieval, among higher vocational students received from the media of information ability is one of the information. Though the construction of Self-media platform, schools, teachers and other educators in view of the initiative from the media, is to take positive measures to address these challenges. This is a positive attitude that has to be taken in the context of the media. Otherwise, the negative information from Self-media will become mainstream. The mainstream of the media information is the need for educators to the initiative of their occupation.

Strengthening the Education of Students' Network Ethics. Network ethics is an important content of contemporary ethics education. Higher vocational students is the recipient and communicators of Self-media network information, if there is no better network ethics, will not be able to identify [3]. Ethics to regulate the relevant information dissemination behavior is an important component of the purification of the information environment. Therefore, higher vocational schools must strengthen the network ethics education for students, set up relevant general courses, so that all students have a better understanding of the network, grasp the legal ethical limits of network information dissemination, cannot inadvertently become a provider of negative information network or communicators. Through the analysis of the typical case, the course can display the necessity of the network ethic specification intuitively and vividly, as well as the understanding of the harm and the legal liability of the violation of ethical moral information.

Improve the Ability of Ideological and Political Education. The team of ideological and political education in higher vocational colleges includes teachers, students' working departments, instructors and courses. At present, higher vocational colleges have paid insufficient attention to improve personnel ability of ideological and political education. Therefore, it will lower the effectiveness of ideological and political education, cannot meet the actual needs of students and carry out related work. The construction of the personnel team needs to improve its ability, such as teaching skills, ability to interact with students, ability to serve students' needs and so on. The educator and the educated should be mutual subject, the educator is not completely passive acceptance, and the educator's teaching is not a simple indoctrination, spoon-feeding, but guided, heuristic. The ideological and political education work team of vocational students must also be able to seize the characteristics of the current Self-media era, and fully enhance their ability to provide basic protection for efficient ideological and political education.

In conclusion, the emergence of the media has changed the way people communicate, the spread of information and access to become more convenient. However, the influence of Self-media on the ideological and political education of higher vocational education is dialectical. In this context, the stakeholders of the ideological and political education of higher vocational education should face 
the impact from Self-media, actively play its positive side, and take countermeasures to reduce its negative impact. So as to better enhance the ideological and political education work.

\section{References}

[1] Chen Huan, Chen Qiaoling. The study of self-education in Ideological and political education of higher vocational students $[\mathrm{J}]$. Contemporary educational practice and teaching research, $2015,8: 15$.

[2] Peng Li. Under the new situation, how to do [J]. Vocational College Students Ideological and political education knowledge Herald, 2016, 45:14.

[3] The history of. Since Jun [D]. media on the ideological and political education and Countermeasures of North Central University, 2015

[4] Dou Huiying, Zhou Fangqiu. Influence of media on College Students' Ideological and political education [J]. Journal of Liaoning University of Technology (SOCIAL SCIENCE EDITION), 2012, 6:70. 